\title{
Mapping the Potential and Quality of Limestone Rocks Using Remote Sensing Method (Study Case: Semanding, Sub District Tuban)
}

\author{
Bangun Muljo Sukojo and Rizki Ramdhani
}

\begin{abstract}
The mine Exploration is an activity to find the points where an area could be mined and the area is still mined, for economic value. One of the most important in the work of mining is the calculation of the estimated potential of mine. Estimation of the potential mine played an important role in determining the amount of work the quality, production, how the mining is done, even to estimate the time required to do the mining. With the advancement of technology in the field of remote sensing, computation of the vast potential of the estimation and the quality of limestone can be done using high resolution satellite image data one is Quickbird. Satellite image data can be used for a wide range of research, such as the mapping of rock quality in relation to the exploration of natural resources. Vast potential of Cretaceous rocks in Semanding sub district is dominated by the high potential of an area of 5480,479 ha. To a limestone rock quality obtained based on limestone CaCO3 levels, the most highs quality i.e. have levels of CaCO3 amounted to $6.81 \%$.
\end{abstract}

Keywords-

\section{INTRODUCTION}

Indonesia is a country which is rich in mining goods, both mineral and metal materials. Various areas in Indonesia have mineral resources in the form of various types of mines/minerals. Limestone $(\mathrm{CaCO} 3)$ is one of the nonmetallic minerals industry that its potential is very large and spread across the region Indonesia [1]. Most of the content of these rocks in Indonesia is in West Sumatra, East Java, East Kalimantan and Central Kalimantan. One of the main producing areas of limestone is the Semanding Subdistrict, Regency of Tuban, East Java.

Sub Semanding is one town located to the North of the island of Java, in Tuban, East Java. Sub Semanding has a limited territory, namely the North, bordered by the SubDistrict of Tuban, East bordering Subdistrict, South Cross borders the subdistricts of Plumpang and Sub Grabagan, while to the West the subdistrict is bordered by the Merakurak.

Mine exploration is an activity to find the points where an area could be mined and the area is still mined, for economic value. One of the most important in the work of mining is the calculation of the estimated potential of mine. Estimation of the potential mine played an important role in determining the amount of work the quality, production, how the mining is done, even to estimate the time required to do the mining.

Bangun Muljo Sukojo and Rizki Ramdhani are with Department of Geomatics Engineering, Institut Teknologi Sepuluh Nopember, Surabaya, 60111, Indonesia. E-mail: rizkidhani96@gmail.com.
With the advancement of technology in the field of remote sensing, computation of the vast potential of the estimation and the quality of limestone can be done using high resolution satellite image data one is Quickbird. Quickbird is a highresolution satellite image that was released on October 18, 2001 in California, U.S.A. Data satellite imagery can be used for a wide range of research, such as the mapping of rock quality in relation to exploration natural resources. This research is expected to later can be used as a method of spatial data more quickly and efficiently in a broad estimate of the potential mapping and rock chalk without reducing the quality of the measurements in the field.

\section{Methodology}

\section{A. Location}

The location of the final project research was carried out in Semanding Subdistrict, Regency of Tuban, East Java astronomically lies in $111^{\circ} 58^{\prime} 0$ '” $-112^{\circ} 8^{\prime} 45^{\prime \prime} \mathrm{BT}$ and $6^{\circ} 53^{\prime}$ $44^{\prime \prime}-7^{\circ} 1$ ' 24" LS.

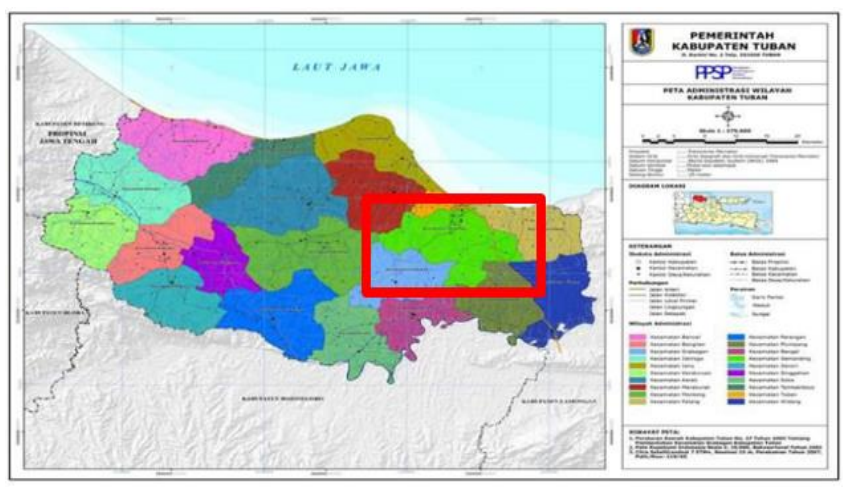

Figure 1. Map of the Administration Area of Tuban (Tuban PPSP, 2017).

Sub Semanding has a limited territory, namely the North, bordered by the Sub-District of Tuban, East bordering Subdistrict, South Cross borders the subdistricts of Plumpang and Sub Grabagan, while to the West the subdistrict is bordered by the Merakurak.

\section{B. Data Processing}

\section{Data collection}

At this stage carried out data collection are used namely Imagery Quickbird, Semanding Subdistrict administrative boundary data, the geological formations of Semanding subdistrict of data as well as data point GCP and ICP is measured using GPS Geodetic Hyper Pro dual frequency. 
The $3^{\text {rd }}$ Geomatics International Conference 2018

July $12^{\text {th }} 2018$, Institut Teknologi Sepuluh Nopember, Surabaya, Indonesia

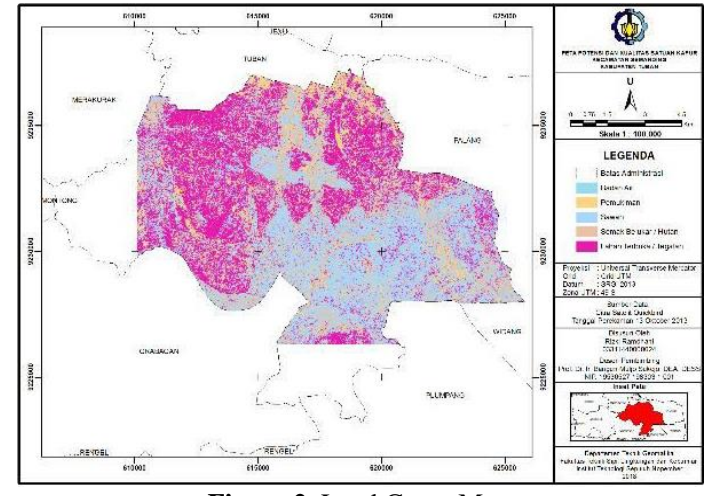

Figure 2. Land Cover Map.

\section{Pansharpening}

Pansharpening performed to panchromatic imagery is the process of merging with multispectral to produce a very high resolutions image that has a color for ease of identification in the placement point of the GCP and ICP.

\section{Geometric Correction}

Geometric correction aims to adjust the coordinates of pixels in the image with the coordinates of the Earth in flat areas. The imagery has not corrected will have geometric errors. So that needs to be done using the coordinate measurement correction GCP by doing the measurement field. Geospatial Information Agency Head rules number 15 Year 2014 has been set the value of the RMS Error allowed is $\leq 1.5$ pixels.

4. The Strength of Figure

Strength of the Figure used for the manufacture of nets and calculated strength. According to [2], the smaller the value the more powerful configuration design NET. The design of the net is considered strong if the value of the design value is jarring $<1$.

\section{Radiometric Correction}

Radiometric correction is a correction given in an image due to errors due to atmospheric conditions, error due to optical system, or the elevation angle of the Sun's fault. This error is an error in the form of a shift in value or degree of grayscale image elements (pixels) on the image so that the necessary corrections in order to approach the price should be. 6. Creation of Vegetation Index Maps

Map making is done by using the algorithm of NDVI, as well as do the classification and Scoring.

\section{Making Geological Map}

Data elements of Geology obtained in shapefile and then do Scoring on the data available.

\section{Land Cover map making}

Map making is done using supervised classification: maximum likelihood, as well as calculating the matrix confusion and do Scoring.

9. The table quality of Limestone

Samples obtained laboratory test done to get the levels of $\mathrm{CaCO} 3$ is contained in the limestone.

\section{Testing thoroughness}

The accuracy test is done to do some checking between the results of image processing with measurement data in the field.

\section{Scoring}

The method of Scoring is based the giving of value in each land unit in accordance with its characteristics.

12. Overlay and Reclassification

Against three overlays a map that has been given the dignity that is a map of land cover, vegetation index map and geological map in order to get a broad limestone rock potential map as well as showing the limestone sample point match quality. Reclassification is done by dividing the class into 5 potential Cretaceous rocks.

\section{RESULT AND DISCUSSION}

\section{A. Result}

\section{Land Cover Map}

Land cover map was created from a data source with Quickbird satellite image recording date October 13, 2013 who have corrected geometric and radiometric correction. Map making is done with digital interpretation method using Supervised Classification: Maximum Likelihood method which assumes that statistics for each class in each band are normally distributed and counting the probability that any given pixel belongs to a particular class and obtained the value matrix confusion of $86.42 \%$.

Research on land cover classification based on SNI Land Cover Classification 7645:2010. Research on region generated 5 land cover types i.e., bodies of water, settlements, fields, scrub and open land/Moor. The results of the land cover map of the Sub-District of Semanding shown in Figure 2. The following is a Table of land cover classification and large:

TABLE 1.

ClassificATION AND EXTENT OF LAND COVER

\begin{tabular}{cll} 
Class & Land Cover & Extents (ha) \\
\hline 1 & Waters & 188.02 \\
2 & Open Land/Moor 3609.34 \\
3 & The settlement & 1653.64 \\
4 & Rice fields & 4310.90 \\
5 & The Bush/Jungle & 1234.47 \\
\hline
\end{tabular}

Land cover classification of the results of this test needs to be done by adjusting the accuracy of land coverage classification of land cover in the image of the situation in the field. This precision test using the 79 point samples taken randomly in the area of research.

Land cover is one of the driving factors for the formation of limestone rocks. Areas such as dense forest will have the content of $\mathrm{CO} 2$ in the soil due to the abundance of the organic remains of the reshuffle (branches, twigs, leaves, animal carcasses) by micro-organisms. The greater the concentration of $\mathrm{CO} 2$ in the water the higher the level of solvency of the water against the limestone [3].

According to [4], The existence of the dissolving process by water which runs continuously in a karst area will produce a wide range of new creations that would indicate an area included in the levels where the karst cycle occurs. A typical form-happens one i.e. terra rossa, red clay that is found on the surface. This land is the dissolving of residual that is not transported into the crevices of rocks. This land is 
usually utilized by residents around the karst to tillage, with plant fillers peanuts, corn and chili.

Based on the parameters of this land cover, then to identify potential areas of limestone on the classification of land cover land cover is open land/Moor and shrubs.

2. Vegetation Index Map

A map of the vegetation Index is created from the data source with the Quickbird satellite imagery recording date October 13, 2013 who have corrected geometric and radiometric correction. Map making is done by doing a calculation algorithm NDVI.

From processing research on the NDVI obtained the lowest value and the highest value of $0.146-0.608$. The lower the value of NDVI, then the area the higher the potential presence of limestone rocks, vice versa [4]. This is due to the limestone rocks are often found in fields/Moor.

Determination of classes of vegetation index NDVI algorithm is done based on Permen No: P. 12/Menhut-II/2012 are divided into five classifications. Grade land is not vegetation, the greenery is very low, low green, greenish, and are the high value of the range with a greenish as follows:

TABLE 2.

The Classification of Vegetation Density Level (PeRmen No: P.12/MENHUT-II/2012 2012)

\begin{tabular}{ccl}
\hline \hline Class & The Range of Value & The Level of Density \\
\hline 1 & $-1 \mathrm{~s} / \mathrm{d}-0.03$ & Land is not Vegetation \\
2 & $-0.03 \mathrm{~s} / \mathrm{d} 0.15$ & The Greenery is Very Low \\
3 & $0.15 \mathrm{~s} / \mathrm{d} 0.25$ & The Low-Green \\
4 & $0.25 \mathrm{~s} / \mathrm{d} 0.35$ & Greenish \\
5 & $0.35 \mathrm{~s} / \mathrm{d} 1$ & The Greenery is High \\
\hline \hline
\end{tabular}

Following are the results of a map of the vegetation index NDVI using algorithms and classification Table along with breadth.

TABLE 3.

THE CLASSIFICATION AND EXTENT OF VEGETATION INDEX

\begin{tabular}{cclc}
\hline \hline Class & NDVI & Category & $\begin{array}{c}\text { Extentes } \\
\text { (ha) }\end{array}$ \\
\hline 1 & $0.146 \mathrm{~s} / \mathrm{d}-0.03$ & Land is not Vegetation & 5.262 \\
2 & $-0.03 \mathrm{~s} / \mathrm{d} 0.15$ & The Greenery is Very & 3316.608 \\
3 & $0.15 \mathrm{~s} / \mathrm{d} 0.25$ & Tow & 3727.882 \\
4 & $0.25 \mathrm{~s} / \mathrm{d} 0.35$ & Greenish & 1898.317 \\
5 & $0.35 \mathrm{~s} / \mathrm{d} 0.608$ & The Greenery is High & 2041.419 \\
\hline \hline
\end{tabular}

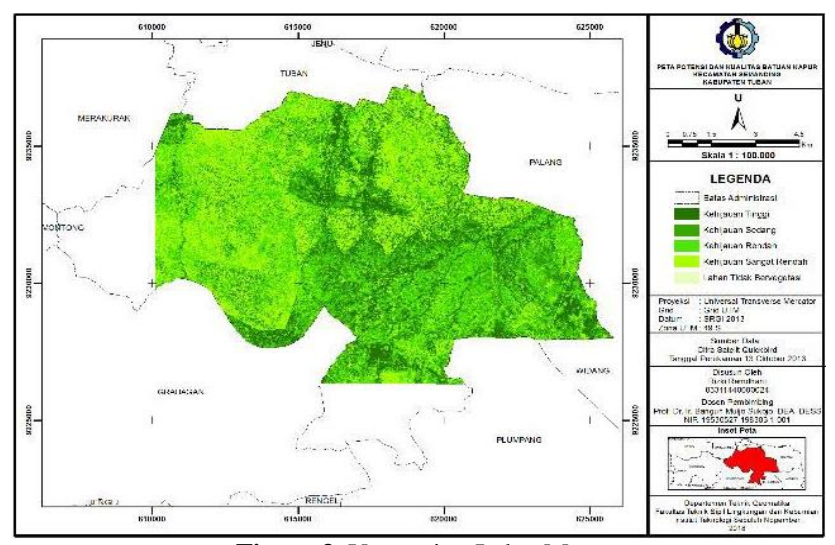

Figure 3. Vegetation Index Map.
If the density parameters of the vegetation, stated that one of the conditions the formation of karst area (with a predominance of limestone and dolomite) is to have land cover vegetation with high density. But from the results of image processing and interpretation of the image get results that vegetation index that is in a location that has the potential of the limestone type green is very low and greenish low so the lower the value of the greenish the potential presence of limestone rocks. That is because as it has been in the abovementioned areas of bushland into open land/Moor [4].

3. Geologic Map

The geological formation of the data obtained in the form of vector format covering the whole area shapefile subdistrict of Semanding. The Geological Formation of the data obtained as a result of the classification and extent as follows:

TABLE 4.

ClasSiFICATION AND EXTENT OF GEOLOGY

\begin{tabular}{clc}
\hline \hline Class & Rock Constituents & Extents (ha) \\
\hline 1 & Alluvium & 879.52 \\
2 & Ngrayong Formation & 200.15 \\
3 & Batulanau Member Kujung Formation & 370.21 \\
4 & Batulempung Member Kujung Formation & 548.82 \\
5 & Formation of Tuban & 2328.16 \\
6 & Paciran Formation & 6473.38 \\
7 & Limestone Formations, The Member of & 189.47 \\
\hline
\end{tabular}

Based on the results of the classification, the rocks that are in the location of the research include:

a. The Alluvium

In this formation contains sand, clay, silt, and gravel. The formation is widely found around rivers and the coast.

b. Claystone Member Kujung Formation

Claystone a portion of its current state with distraction clay gray silt stone young, thin layers of marl grey very young local sandstones and its current state, the number of finegrained and violence of the marl layers increasing the top.

c. Prupu, Member of the Limestone Formation Kujung

Tersemenkan, compact limestone, forming the outcropsresistant outcrops, large bongkah- bongkah spread over the surface. Interlude-interlude marls and batulempung are not exposed and only known from wells and drilling holes.

\section{d. Batulanau Member Kujung Formation}

Made up of mud, a part of lime archeological and clays. The bottom layer-a thin layer of greenish-gray colored clay stone, the temple looks thin, layered, containing foraminifera big, small, large, Pelecypoda and the rest of the plant, concrescence dolomite iron and pyrite.

e. Formation of Ngrayong

In this formation contains A Special Quartz Sandstones with clay stone and limestone

f. Paciran Formation

Consist of limestone, limestone and dolomite. White, grey, Brown and reddish, organic with fragments of foraminifera, corals, algae large and mollusks.

g. Formation of Tuban 
The $3^{\text {rd }}$ Geomatics International Conference 2018

July $12^{\text {th }} 2018$, Institut Teknologi Sepuluh Nopember, Surabaya, Indonesia

Made up of mud, grey, green and yellowish grey with interludes limestone and clay. concrescence and clay stone contain the local temple looks iron.

Limestone in the area there are many Tuban at Paciran formation, the formation of Kujung, and the formation of Tuban [5].

4. Quality Limestone

The quality of the limestone obtained from the results of laboratory analysis to obtain levels of $\mathrm{CaCO} 3$ in the limestone obtained on areas of research. The higher the levels of $\mathrm{CaCO} 3$ on limestone rocks, then the higher the quality. Testing the levels of $\mathrm{CaCO} 3$ in the sample obtained in field of limestone is done with the method Kompleksometri.

Titration kompleksometri is a titration based on compound complex formation reactions between the metal ion with complex-forming substances. It turns out that when multiple metal ions present in an aqueous solution, so titration with EDTA would show the sum of all existing metal ions in solution [6].

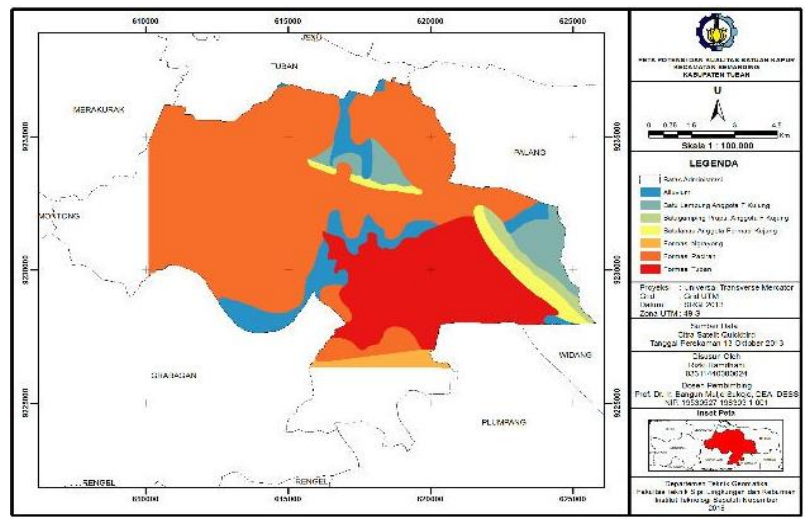

Figure 4. Geological Map.

Following are the results of the analysis of $\mathrm{CaCO} 3$ obtained from Chemical Laboratory test results-ITS on 17 April 2018.

TABLE 5 .

RESUlts ANALYSIS OF CACO3 (ChEMICAL LABORATORY ITS, 2018)

\begin{tabular}{cccc}
\multicolumn{4}{c}{ The LimestONE SAMPLE SURVEY DATA } \\
\hline \hline No & Point & Result Analysis $\left(\mathbf{C a C O}_{3}\right)$ & Method \\
\hline 1 & S1 & $5.95 \%$ & \\
2 & S2 & $6.81 \%$ & \\
3 & S3 & $5.94 \%$ & \\
4 & S4 & $6.27 \%$ & \\
5 & S5 & $6.05 \%$ & \\
6 & S6 & $6.06 \%$ & \\
7 & S7 & $6.59 \%$ & \\
8 & S8 & $4.54 \%$ & \\
9 & S9 & $5.95 \%$ & \\
10 & S10 & $6.06 \%$ & \\
11 & S11 & $3.89 \%$ & \\
\hline \hline
\end{tabular}

From the results of the analysis in Table 3.5 analysis results can be categorized into three levels of $\mathrm{CaCO} 3$ category. The following Table of quality limestone rocks.
TABLE 6

TABLE OF QUALITY LIMESTONE

\begin{tabular}{ccc}
\hline \hline No & Limestone Quality & Content of CaCO3)\% \\
\hline 1 & Low Quality & $3.89-4.86$ \\
2 & Medium Quality & $4.86-5.83$ \\
3 & High Quality & $5.83-6.81$ \\
\hline \hline
\end{tabular}

According to [7], based on the levels of clays in the limestone and its use in industry can be differentiated into:

a. Chalk white, when $90 \% \mathrm{CaCO} 3>$, clay $<10 \%$

b. Lime hydraulic, when $75 \% \mathrm{CaCO}-90 \%$, clay $10 \%$ $25 \%$

c. Lime cement when $\mathrm{CaCO} 370 \%-75 \%$ clay, $25 \%-30 \%$

d. Roman Limestone (Pozolan) when $60 \%$ CaCO3-70\% clay, $30 \%-40 \%$

e. Portland cement when $\mathrm{CaCO} 325 \%-60 \%, 40 \%$ clay$75 \%$

Based on the levels of clays in the limestone under the classification of Effendy, limestone in Semanding does not match the use as industrial materials, but based on observation in the field, the limestone in the Semanding widely used as Kumbung Stone. Kumbung Stone is usually used as the Foundation of the building.

5. Map the Potential and Quality of Limestone

Map the potential and quality of limestone rocks created by overlaying against 3 maps (a map of land cover, vegetation index map and geological map) and the results of the laboratory test levels of $\mathrm{CaCO} 3$ on 11 samples of the rock chalk. On the map is done Scoring 3 in each class, the higher score then the area more and potentially the presence of limestone rocks, the higher the levels of $\mathrm{CaCO} 3$ high quality limestone rocks. Here is the Table that contains the Scoring of each parameter of the existence of potential rock chalk and limestone grade Table.

TABLE 7.

SCORING PARAMETER DETERMinATION OF THE POTENTIAL OF CRETACEOUS ROCKS

\begin{tabular}{|c|c|c|c|c|}
\hline No & Parameters & Class & Score & Weighting (\%) \\
\hline \multirow[t]{6}{*}{1} & & Green High & 1 & \multirow{6}{*}{20} \\
\hline & \multirow{5}{*}{$\begin{array}{l}\text { Vaastation } \\
\text { Tudne. }\end{array}$} & The Greens Are & 2 & \\
\hline & & The Low-Green & 3 & \\
\hline & & Ihe Greenery Is & 7 & \\
\hline & & Very Low & & \\
\hline & & Vegetation & 2 & \\
\hline \multirow[t]{5}{*}{2} & & Body of Wzter & 0 & \multirow{7}{*}{30} \\
\hline & $\pi \mathrm{m} A$ & The settlement & 1 & \\
\hline & $\mathrm{Cm}_{\mathrm{m}}$ & Rice fields & 2 & \\
\hline & & The Bush Jungle & 3 & \\
\hline & \multirow{9}{*}{$\begin{array}{l}\text { Geological } \\
\text { Map }\end{array}$} & Upen Lara Aloor & 4 & \\
\hline \multirow{8}{*}{3} & & Alluvilun & 1 & \\
\hline & & Formation & 2 & \\
\hline & & Batulanw Member & & \multirow{6}{*}{50} \\
\hline & & Buivaz Formation & 4 & \\
\hline & & Extulexpouns. & & \\
\hline & & Member Kulung & 4 & \\
\hline & & Fonmation of Tylan & 5 & \\
\hline & & Pacian Formation & 6 & \\
\hline
\end{tabular}




\begin{tabular}{|c|c|c|c|}
\hline No Parameters & Class & Stort & Weighting (\%) \\
\hline & $\begin{array}{c}\text { Limestone } \\
\text { Formations, The } \\
\text { Members of Powen } \\
\text { Kuiung }\end{array}$ & v & \\
\hline
\end{tabular}

TABLE 8.

TABLE OF QUALITY LIMESTONE

\begin{tabular}{crc}
\hline Point & $\begin{array}{r}\text { Result Analissis } \\
\text { S11 }\end{array}$ & Quality \\
\hline S8 & $4.89 \%$ & Low Quality \\
\hline S3 & $5.94 \%$ & \\
S1 & $5.95 \%$ & \\
S9 & $5.95 \%$ & \\
S5 & $6.05 \%$ & \\
S6 & $6.06 \%$ & High Quality \\
S10 & $6.06 \%$ & \\
S4 & $6.27 \%$ & \\
S7 & $6.59 \%$ & \\
S2 & $6.81 \%$ & \\
\hline
\end{tabular}

Overlay is performed using the method of intersection. Stacking is a method of an Intersection between two graphic data, but if the outer boundary of the two graphic data are not the same, then the processing is performed only on the shoulder. After that continued with the calculation of the amount of dignity and appropriate intervals anniversary classification specified by the following formula:

$$
\text { Interval }=\frac{\max \text { value }-\min \text { value }}{\text { total class }}
$$

The classification is divided into five classes so that the interval of calculation is like the following Figure.

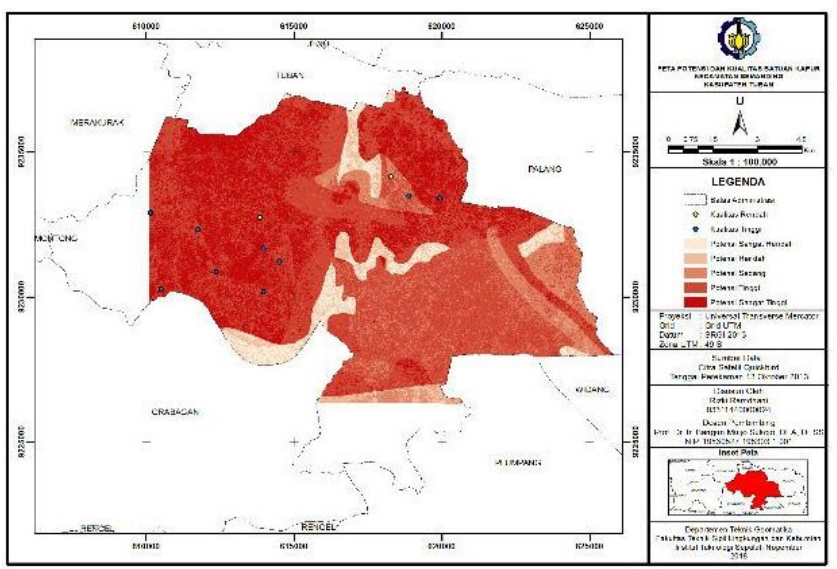

Figure 5. Map the Potential and Quality of Limestone.

From the results obtained as a broad classification of each potential class of rocks such as limestone the following table.

TABLE 9.

Classification, Extents, AND the Percentage of Potential LIMESTONE

\begin{tabular}{lrrr}
\hline \hline Category & Extent (ha) & Percentage (\%) & \\
\hline Very Low Potential & 536.274 & 4.880 \\
Low Potential & 494.327 & 4.499 \\
Medium Potentials & 1287.499 & 11.717 \\
High Potential & 5480.479 & 49.876 \\
Very High Potential & 3189.694 & 29.028 \\
\hline \hline
\end{tabular}

From the results of extensive calculations and the percentage obtained that Semanding dominated by high levels of potential with an area of 5480,479ha.

\section{A. Analysis of the Results of The Processing}

1. Test the accuracy of land Coverage

The results of the classification accuracy of test caps need to be performed to Test the accuracy of checking between the results of processing in image and measurement in the field. Test the accuracy of this using a random sample of 79 point spread on location based on GCP and ICP point area. Data retrieval using handheld GPS by noting coordinates and its land cover categories. Measurements carried out on 30 March-1 April 2017.

By doing the calculation accuracy of land coverage of trials, obtained accuracy of 86\%. Geospatial Information Agency Head rules the number of 15 years has set 2014 test thoroughness of land cover should have carefulness $>85 \%$.

2. Vegetation Index Value Correlation Test

The results of the vegetation index value to do test the correlation. This correlation test is performed with compare value of NDVI in the image with the value NDVI obtained in field. This correlation test using 20 points samples taken randomly and evenly spread on the area of research. Data retrieval is performed using a camera shooting with NDVI by noting the sample point coordinates. Data retrieval is performed on 30 March-1 April 2017. The following is the graph of the correlation of image data with a data field for the value of vegetation index.

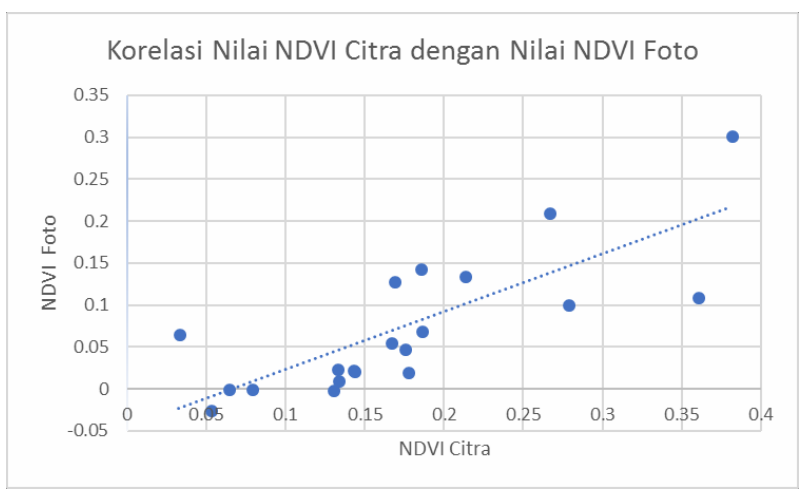

Figure 6. The Graph of The Correlation of NDVI.

Image Quickbird and NDVI Photos As indicated by the graph above, the value of NDVI image processing measurement results have a different value to the value of NDVI in the field. This is done to find out the extent of correlation or a proximity value of NDVI image processing measurement results with the value NDVI results photo camera NDVI. The correlation values range from 1 to- 1 , the value of getting closer to 1 or- 1 means the relationship between two variables is increasingly strong. Conversely, if a value close to 0 means the relationship between two variables is getting weak. Positive values indicate a direct relationship ( $\mathrm{X}$, then $\mathrm{Y}$ ride up) while a negative value indicates reverse relationship ( $\mathrm{X}$, then $\mathrm{Y}$ ride down). The data used in the partial correlation usually have a scale interval or 
The $3^{\text {rd }}$ Geomatics International Conference 2018

July $12^{\text {th }} 2018$, Institut Teknologi Sepuluh Nopember, Surabaya, Indonesia

ratio. The following is an analysis of the correlation coefficient for [8]. $0.00-0.199=$ very low

$$
\begin{aligned}
& 0.20-0.399=\text { low } \\
& 0.40-0.599=\text { moderate } \\
& 0.60-0.799=\text { strong } \\
& 0.80-1.000=\text { very strong }
\end{aligned}
$$

Test results correlation yields a value of correlation $(\mathrm{R})$ by 0.781 . This value specifies the correlation value of NDVI Image Quickbird with cameras NDVI categories include stronger so it can be concluded the processing of Quickbird imagery on NDVI is in compliance.

\section{B. Analysis of the Potential and Quality of Limestone}

The results of the map the potential and quality of limestone rocks Subdistrict Semanding obtained the broad potential of Cretaceous rocks is dominated by the high potential of an area of 5054.96 ha. To a limestone rock quality obtained based on limestone $\mathrm{CaCO} 3$ levels, the most high quality i.e. have levels of $\mathrm{CaCO} 3$ amounted to $6.81 \%$.

From the results of a map of the potential and quality of limestone rocks of Semanding Subdistrict, the magnitude of the potential high on Sub-district Semanding due to the formation of the Geological Map at Paciran. Where this formation contains limestone, limestone and dolomite dolomitan. Another factor is the low vegetation index and land cover in the form of open land/Moor. For the quality of limestone rocks dominated by high quality, value levels of $\mathrm{CaCO} 3$ was at $5.83 \%$ range $-6.81 \%$.

\section{CONCLUSSION}

Based on the results of research on Mapping the potential and quality of Limestone Rocks Using remote sensing Methods in district Semanding, Tuban by utilizing satellite imagery Quickbird, then obtained some final conclusions, namely:
1. Data of Quickbird satellite imagery can be used for map making potential and the quality of the limestone rocks in Semanding Subdistrict, Tuban.

2. Sub Semanding is dominated by high levels of potential with an area of 5054.96 ha, while for very low potential level 536,274 ha, low potential 494,327 ha, 1287,499 ha are potential and a very high potential of 3189,694 ha.

3. The quality of the limestone Semanding Subdistrict have a high percentage of the most quality levels of $\mathrm{CaCO} 3$ i.e. $6.81 \%$ and lowest quality with value percentage of $\mathrm{CaCO} 3$ levels i.e. $3.89 \%$.

\section{ACKNOWLEDGMENT}

Author thanks to Geospatial Laboratory-ITS for the support of data and guidance during this research.

\section{REFERENCES}

[1] I. Shubri, E. dan Armin, "Penentuan Kualitas Batu Kapur dari Desa Halaban Kabupaten Lima Puluh Kota di Laboratorium Dinas Energi dan Sumber Daya Mineral Provinsi Sumatera Barat," Universitas Bung Hatta, 2014.

[2] Z. Abidin, H, Penentuan Posisi Dengan GPS dan Aplikasinya. PT. Pradnya Paramita, 2002.

[3] D. Al Majid, "Pemetaan Potensi Batuan Kapur Menggunakan Metode Penginderaan Jauh dan Sistem Informasi Geografis di Kabupaten Tuban," Surabaya, 2017.

[4] Nurjannah, "Pemodelan Estimasi Potensi Tambang Batu Kapur Dari Hasil Analisa Data Citra Satelit Landsat 7 ETM+ (Studi Kasus: Tambang Batu Kapur PT. Semen Gresik Persero Tbk. Pabrik Tuban)," 2013.

[5] H. dan Suharsono, Peta Geologi lembar Tuban, Jawa Timur. 1997.

[6] S. Khopkar, Konsep Dasar Kimia Analitik. Jakarta: UI Press, 2002.

[7] M. Effendi, "Analisa Kimia dan Identifikasi Mutu Batu Kapur Tuban Berdasarkan Syarat Mutu Batu Kapur untuk Pembuatan Keramik Halus (SII.1279-85)," Bali, 2004.

[8] Sugiyono, Metodologi Penelitian Bisnis. Jakarta: Gramedia, 2007. 